\title{
"Go Out from Your Sign": Rashi to Genesis 15:5 as a Reference to Astrological Primary Direction - Its Background in Rabbinic Literature and Parallels in Abraham bar Ḥiyya
}

\author{
Ola WikAnder (The Centre For Theology and Religious Study, \\ Lund UNIVERSITY \& THE SWEDISH COLlEgIUM FOR ADVANCED \\ STUDY) ${ }^{1}$
}

\begin{abstract}
This article suggests that Rashi's exegetical commentary to Gen 15:5, in which Abram counts the stars, is meant to invoke an association with the astrological technique known as Primary Directions (based on equating one degree of Right Ascension in the rotation of the earth around its axis with one year of life), which was one of the main methods of prognostication in pre-modern astrology - beginning already in Hellenistic times and quite central in Mediaeval astrological thinking. Rabbinic sources discussing the relevant
\end{abstract}

* Submitted: 17/04/2020; peer-reviewed: 05/11/2020; accepted: 15/11/2020. Ola Wikander, "Go out from Your Sign": Rashi to Genesis 15:5 as a Reference to Astrological Primary Direction - Its Background in Rabbinic Literature and Parallels in Abraham bar Hiyya," Old Testament Essays 33 no. 3 (2020): 556-581. DOI: https://doi.org/10.17159/2312-3621/2020/v33n3a11.

This article has been written during my work as a scholar in the Pro Futura Scientia program, funded by Riksbankens Jubileumsfond and the Swedish Collegium for Advanced Study. Many thanks are due to Martin Gansten for reading through the essay and for his many thoughtful suggestions - and references to Hellenistic, Mediaeval Jewish and Indian astrological sources and many similar insights. My appreciation also goes to members of the Lund Old Testament seminar for their illuminating comments. A note on ancient references-Hebrew and Aramaic texts in this article are generally quoted according to the editions in Sefaria, www.sefaria.org (unless stated otherwise). The Rashi texts to Genesis are also based on Rabbi Yisrael Isser Zvi Herczeg et al., eds., The Sapirstein Edition: The Torah with Rashi's Commentary. Translated, Annotated, and Elucidated, Vol. 1: Bereishis/Genesis (New York: Mesorah Publications, 1995). Translations are my own unless otherwise stated. I have added some punctuation for ease of reading. I have also vocalised the transliterations; one should note that the vocalisation of Jewish Babylonian Aramaic is a precarious and uncertain endeavour - caveat lector! cf. Elitzur A. Bar-Asher Siegal, Introduction to the Grammar of Jewish Babylonian Aramaic (Münster: Ugarit-Verlag, 2013), 42. References to Ptolemy's Tetrabiblos/Apotelesmatika are to Wolfgang Hübner, ed., Claudii Ptolemaei opera quae exstant omnia, volume III 1: AПOTEAE (Stutgardiae et Lipsiae: Teubner, 1998) and Frank E. Robbins, ed., Ptolemy: Tetrabiblos (Cambridge: Harvard University Press, 1940). 
biblical passage and the idea of Abraham as a supreme astrologer are analysed, along with parallel material from Abraham bar Hiyya and Ibn 'Ezrā. The article examines both what Rashi kept and what he removed from his Rabbinic sources, and elaborates on the role of astrological thinking in his milieu.

KEYWORDS: Rashi, Genesis 15:5, Abraham, Astrology, Primary Directions, Bar Hiiyya, Ibn 'Ezrā; bShabbat 156 a-b, Genesis Rabbah, Divination, 'iștagnînût

\section{A INTRODUCTION}

The present article investigates the possibility that Rashi's commentary to Genesis 15:5 subtextually invokes a reference to the astrological technique known as Primary Directions - one of the most important of such techniques in the Western and Perso-Arabic astrological traditions of Antiquity and the Middle Ages (and one well-known in the Jewish astrology of his day). As we shall see, it seems that Rashi used earlier textual material in a specific way to create such a reference, and even did it in a way that would make especially good sense in his own physical location. The questions, then, are (a) whether there is such a reference, and if so, (b) how Rashi may have read and chosen his sources to bring about an association to this specific technique, as well as (c) how this may have appeared to astrologically well-read Jewish audiences of his day (and, of course, the relationship between these two latter points). As we shall see in detail later in the present article, Rashi is known to have possessed astrological knowledge, which makes these questions worth investigating.

The biblical verse in question famously includes a reference to contemplation of the stars in the context of Abram's current lack of an heir:

Wayyōṣè 'ōtô hahûṣ̂a wayyō'mer habbeț-nā' haššāmaymâ ûsěpōr hakkôkābîm 'im-tûkal lispōr 'ōtām wayyō'mer lô kōh yihyeh zar'ekā

And he [YHWH] brought him [Abram] outside and said: "Look up to the heavens and [try to] count the stars to see if you can count them [all]." And he said to him: "Such your offspring will be."

There is an early and persistent tradition in Northwest Semitic mythological storytelling of associating knowledge of the stars with deep insight. One famous instance of this can be found already in the Ugaritic Epic of Aqhat (14th-13th century BCE), in which Pughat, the sister of the eponymous hero (and, in actuality, quite as much of a heroine as he is a hero, if not more) is referred to as $y d^{\prime}$ t hlk kbkbm, "she who knows the ways of the stars." In that text, this knowledge of the stars is counted as the same level of wisdom that is

2 KTU 1.19 II $1-3$ and IV 37. 
otherwise only applied to El, the father of the gods himself. ${ }^{3}$ Thus, it is not surprising that Abram's introduction to the divine covenant invokes stargazing as a way of insight into its nature (albeit in an almost ironic way, as Abraham is presupposed not to be able to count the stars). To be sure, the Genesis text itself does not describe the counting of the stars as sagely in and of itself, but such a "direction of interpretation" is certainly there as a possibility given the previous literary tradition, and, as we shall see, this is precisely the trajectory that many later Jewish interpreters chose. In this article, I will examine how this contemplation of the starry skies on the part of Abra(ha)m was subsequently reinterpreted and expanded in Jewish tradition. Specifically, I will suggest that it subsequently acquired an association with a certain rather complicated technique of astral divination - in a way that would greatly have surprised the original author of the text, yet, in its own way, carries forward the ancient narrative trope of the wise stargazer, albeit in a transformed manner.

Already at the outset, it should be noted that my point is not that the actual Genesis text be read contextually-historically as implying that the Abraham character should be understood as an astrologer in the strict sense of that word. What is there originally is a motif concerning "starry wisdom" and of associating deep knowledge with the stars (which can also be seen in the Aqhat text). It is in subsequent, hermeneutical tradition that the motif is interpreted as a reference to what we would call "astrology" today - even though Abraham's Chaldean origin in the text itself may certainly have been meant to invoke an association with Babylonian astral divination from the start - but this is not actually astrology in the narrower sense of the word - cf. footnote 4 . Thus, it is the later reworking and Fortschreibung of this general "wise man interpreting the skies" motif (which probably is there in the text) into a specific interpretation of astrological doctrine that I shall be examining in the following. I shall return to this methodological and hermeneutic issue later on in the article (under the heading Rashi's Reading and the Historical Background of the Text), after the main arguments have been put forward. With this in mind, we shall begin by discussing how the interpretive tradition that views Abraham as an astrologer

3 Baruch Margalit, The Ugaritic Poem of AQHT: Text, Translation, Commentary (Berlin: de Gruyter, 1989), 365 makes the interesting point that Pughat (given her knowledge of the stars) is the only dramatis persona about which the epic uses the verb $y d^{\prime}$ except for El, the super wise god himself (also quoted in Jacqueline Vayntrub, "Transmission and Mortal Anxiety in the Tale of Aqhat," in Like 'Ilu Are You Wise: Studies in Northwest Semitic Languages and Literature in Honor of Dennis G. Pardee (ed. H.H. Hardy, Joseph Lam and Eric D. Raymonds; Oriental Institute Publications, https://core.ac.uk/reader/147828343 (preprint version). See fn. 52 and the main text on that page, where the point is used to highlight the role of the female protagonist/avenger of the story in contrast to the "conventional" way of guaranteeing familial survival through the birth of a son initially sought by Danel. Note that the issue in the Abra(ha)m narrative is also one of getting a legitimate son and securing descendants. 
was first expressed, after which we will consider Rashi himself and the astrological technique - Primary Directions - that I believe he is invoking.

\section{B ABRA(HA)M THE ASTROLOGER IN JEWISH LITERARY TRADITION}

From early in the Jewish exegetical tradition, there has been a tendency to interpret Genesis 15:5 and its stargazing as some sort of reference to astral divination, specifically to astrology. ${ }^{4}$ In contrast to how some exponents of critical biblical study, for example, von Rad, view the beginning of chapter 15 as derived from a cultic setting (divine revelation, followed by a salvation oracle and an acknowledgment of șĕd $\bar{a} q \hat{a}),{ }^{5}$ early Jewish exegesis clearly seems to have seen Abram here as a "wise man of Chaldea," so to speak, well-versed in astral divination. A tradition about Abraham as an astrologer can be found already in Josephus (Ant. Iud. I 7.1.2, attributing the idea to Berossus), and another early reference (attributed to the possibly Samaritan writer Pseudo-Eupolemus) can be found in Eusebius of Caesarea (Praep. Evang. IX 17). ${ }^{6}$ Philo mentions Abraham as a knower of the stars (De Abrahamo 69-71), and Pseudo-Philo makes such a connection in his work Biblical Antiquities (18:5). Interestingly, the Qumran text Pseudo-Jubilees appears to allude to a similar astrological connection to the promise of descendants to Abraham (4Q225 2 I 3-8). ${ }^{7}$ It is notable that this tradition seems to have extended to non-Jewish sources as well. The second century CE astrological writer Vettius Valens mentions Abraham as an astrologer of repute (Anthologiae 28-29), as does the fourth century Firmicus Maternus, who lists him along other semi-mythical icons of astrology such as Nechepso-Petosiris (Mathesis 4. Proem. 5; 4.17.2, 5; 4.18.1). ${ }^{8}$

4 Sensu stricto, "astrology" refers only to those methods of astral divination that are based on the calculation of the Ascendant, i.e. "horoscopic astrology."

5 Gerhard von Rad, Genesis: A Commentary (rev. ed.; trans. John H. Marks; London: SCM Press, 1978), 182.

6 For these and other early references to Abraham as an astrologer or astral divinator, see Margaret Barker, The Mother of the Lord, Volume 1: The Lady in the Temple (London \& New York: Bloomsbury T\&T Clark, 2012), 52 and Yuval Harari, Jewish Magic Before the Rise of Kabbalah (trans. Batya Stein; Detroit: Wayne State University Press, 2017), 445-448. The latter also discusses the question of Israel not being subject to astral influences, a topic that will be covered later in this article.

7 On these connections and ancient sources, see Devorah Dimant, "Abraham the Astrologer at Qumran? Observations on Pseudo-Jubilees (4Q225 2 I 3-8)," in Textual Criticism and Dead Sea Scroll Studies in Honour of Julio Trebolle Barrera: Florilegium Complutense (ed. Andrés Piquer Otero and Pablo A. Torijano Morales; Leiden: Brill, 2012). Dimant also mentions the Talmudic passage discussed later in this article, though without analysing it in detail. Ibid., 82.

8 For a discussion of these (and similar) references, see Pieter W. van der Horst, "Did the Gentiles Know Who Abraham Was?" in Abraham, the Nations, and the Hagarites: Jewish, Christian, and Islamic Perspectives on Kinship with Abraham (ed. Martin 
Moving on to Rabbinic sources, the Talmudic passage bBava Batra 16b states that Abra(ha)m was a highly skilled astrologer whom the kings of the east and the west would come to consult, ${ }^{9}$ and it is quite likely that this idea emanates to a great deal from an early exegesis of Genesis 15:5. Such an analysis occurs already in the Genesis Rabbah (44:10, dealing with the somewhat earlier Gen $15: 3):{ }^{10}$

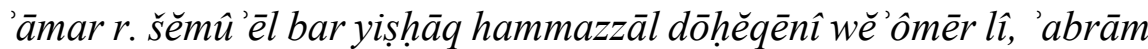
'ên 'att môlîd. 'āmar lô haqqādôš bārûk hû' hēn kidbārêkā 'abrām lō' môlîd 'abrāhām môlîd

Rav Shemuel bar Yișhaq said, [Abram said]: "The star position oppresses me, and it says to me: 'Abram, you will not engender children." The Holy One Blessed Be He said to him: "See, it is like you said - Abram will not engender children, but Abraham will."

The text then says the same about Sarai-Sarai will not bear children, but Sarah will.

The Babylonian Talmud (Shabbat 156a) also interprets Abram's despondency about his ability to engender a child as a question of astrology, with the following dialogue being reported/invented:

'āmar lěpānayw ribbônô šel 'ôlām nistakkaltî bě ișțagnînût šellî

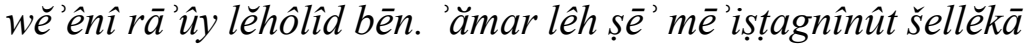

[Abram] said before him: "Lord of the World, I have considered my astral divination, and I am not seen to father a son." [God] said to him: "Depart [lit. "go out"] from your astral divination [...]!"

We shall return to that text in detail later in this article.

Goodman, George H. van Kooten and Jacques T.A.G.M. van Ruiten; Leiden: Brill, 2010), 71-73.

9 A similar opinion appears in Tosefta Kiddushin 5:17, which interprets the blessings Abraham is said to have received from YHWH during his life in Gen 24:1 as referring to astrological knowledge (also mentioned by Yuval Harari; see above, fn 6 . Note that the Sefaria edition does not include this passage).

10 Gregg Gardner, "Astrology in the Talmud: An Analysis of Bavli Shabbat 156," in Heresy and Identity in Late Antiquity (ed. Eduard Iricinschi and Holger M. Zellentin; Tübingen: Mohr Siebeck, 2008), 332 regards the references to astrology in Genesis Rabbah 44 as "an innovation in the exegesis of these verses around the fifth century." Note, however, the much earlier traditions about Abraham as an astrologer mentioned above in the main text. I find it rather unlikely that these had nothing to do with Gen $15: 5$, even though they do not say so outright. 
Genesis Rabbah (44:12) also interprets the reference to YHWH bringing Abram "outside" in an overtly cosmological manner, in a way that appears both to presuppose and to censure his use of astrology outright:

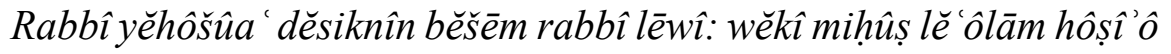

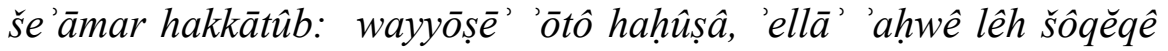
šěmayyā', hêk mâ dĕ'att 'āmar: 'ad lō' 'āśâ 'ereș wẹhụ̂șôt. 'āmar rabbî yĕhûdâ běšèm rabbî yôhănān he élâ 'ôtô lěma lâ mikkippat

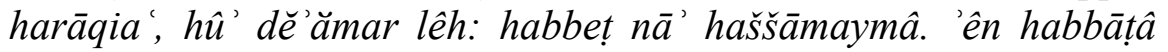

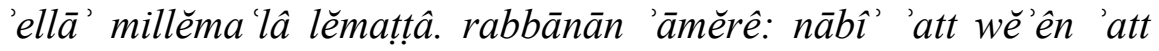

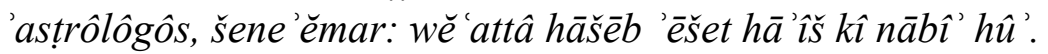

Rabbi Yehoshua Desikhnin [said] in the name of Rabbi Levi: "And thus [God] brought [Abram] out of the world, for the written text says: 'And he brought him outside', but he showed him the places ${ }^{11}$ of the sky, just as you say: "while he had still not made the earth and the outsides [i.e. fields, Prov 8:26]."” Rabbi Yehuda said in the name of Rabbi Yohanan: "He lifted him up above the dome of the firmament, which is why he said to him: 'Look to the heavens!' [The term] 'looking' is nothing else than 'from above to below'." Our Rabbis say: "You are a prophet and not an astrologer! - as it is said: 'And now, return the man's wife, for he is a prophet [...]' [Gen 20:7]."

However, it is in Rashi's commentary that these elements are put together in the way which interests us here. To this, we now move.

\section{RASHI'S SYNTHESIS}

We shall now study Rashi's synthesis and look at his interesting redactions, omissions and word choices. Indeed, the importance of specifically studying Rashi in this way - noting what he kept and what he did not in relation to his sources - is pointed out in the "Publisher's Preface" to the Sapirstein edition of Rashi to Genesis. It states that "Rashi's choice of citations from the voluminous literature of the Sages is in itself a commentary for those who understand the

11 Marcus Jastrow, A Dictionary of the Targumim, Talmud Babli and Yerushalmi, and the Midrashic Literature (New York: W. Drugulin/Luzac/Putnam's Sons, 1903), 1625-

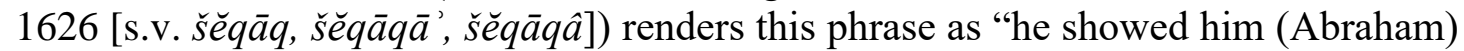
the streets of heaven." However, I believe that a more general translation "place" (which is an attested meaning of the word) is more appropriate than "street," as this could imply an association with "stellar places" and possibly even the twelve mundane houses of a horoscope, known in Greek as $\tau o ́ \pi o l$ ("places"). Such a reference would fit well with the imagery of Abram being lifted above the celestial spheres, providing an excellent view of the twelve "places" (houses) that make of the sphere of the daily (primary) motion. Ibn 'Ezrā later uses bayit for the mundane houses, but it is not unreasonable that a source as early as Genesis Rabbah would choose the more Hellenistic-sounding terminology of "places." 
reasons he selected one or two opinions out of many."12 This is the attitude we shall take here. Rashi's comment on Gen 15:5 runs as follows:

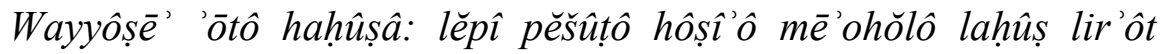
hakkôkābîm ûlěpî midrāšô 'āmar lô șe' mè iștagnînut šellěkā šerā îtā bammazzālôt še'èněkā 'ātîd lěha 'ămîd ben: 'abrām 'ên lô ben 'ăbāl 'abrāhām yēš lo ben, śāray lo' tēlēd 'ăbāl śârâ tēled. 'ănî qôrē' lākem

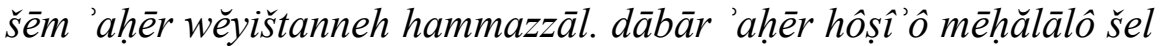
ôlām wěhigbîhô lěma lâ min hakkôkābîm wězehû lěšôn habbātâ milěma lâ lëmattâ

"And he brought him outside": according to its literal meaning - he brought him out from his tent to outdoors to look at the stars, and according to its midrashic interpretation - he said to him: "Depart [lit. 'go out'] from your astral divination, that you saw in the stellar positions that you were not going to beget a son: Abram has no son, but Abraham has a son, Sarai will not give birth, but Sarah will give birth. I am giving both of you a new name, and the stellar position will be changed." Another interpretation: he brought him out from the space of the world and brought him up on high above the stars - and [the expression "looking"] refers to looking from above down below.

It is this combined passage from Rashi that I suggest may include subtextual references to the technique of Primary Directions.

\section{PRIMARY DIRECTIONS AS A TECHNIQUE OF ASTROLOGICAL DIVINATION}

Primary Direction is one of the oldest techniques of traditional, pre-modern astrology (it is known in Greek as ö $\varphi \varepsilon \sigma ı \varsigma$ ["sending out"], in Arabic as tasyīr or at-tasyir with the definite article ["running/letting run"], the latter subsequently borrowed into Mediaeval Latin as athazir or translated as directio). In Hebrew, a verbal root used for carrying out Primary Directions is $n h g$, "to lead" (not used by Rashi but occurring, for example, in Ibn 'Ezrā - see below). The roots of the technique lie already in Hellenistic times, and it was kept as a central practice in the traditions of the Perso-Arabic astrologers of the Middle Ages. It was subsequently imported back into European astrology, where it formed a backbone of astrological prediction until the early 19th century. It was not a part of the theosophically-inspired revival of astrology around the beginning of the 20 th century, no doubt due to its mathematical complexity and focus on concrete predictions of physical events such as deaths, marriages, etcetera, which are quite at odds with the psychologically oriented aims of the reinvented neo-astrology

\footnotetext{
12 Unsigned "Publisher's Preface" to Herczeg et al., The Sapirstein Edition: Rashi, xii.
} 
of the 20th century. In the last two decades, there has been, however, a rediscovery of the technique in parts of the astrological community. ${ }^{13}$

The main idea of Primary Directions is the proposition that the primary motion during the day after a birth - the apparent motion of the sky around the Earth, caused astronomically by the earth's rotation around its own axis - can be interpreted as a sort of "moving horoscope," and that the degrees of that motion (especially across the horizon) can be symbolically equated with a number of years in the native's life. The standard measurement (associated with Claudius Ptolemy, though older than him) is to equate one degree of Right Ascension ${ }^{14}$ with one year of life, which in practice means equating about four minutes of primary motion with one year. The oldest form of Primary Directions is focused on the rising of the various zodiacal signs across the Ascendant (effectively, the horizon) after birth, putting special emphasis on the motion of the so-called terms (ópıa, unequal parts of the signs, regarded as ruled by different planets) across it. ${ }^{15}$ The latter technique is described by Rashi's younger contemporary Ibn 'Ezrā

13 For early examples of the use of Primary Directions in antiquity, see Martin Gansten, "Balbillus and the Method of Aphesis," Greek, Roman and Byzantine Studies 52 (2012): 587 (and for the terminology for Directions in Greek, Arabic and Latin). A general introduction to the history of the technique, its development and various exponents in ancient and Mediaeval literature can be found in idem, Primary Directions: Astrology's Old Master Technique (Bournemouth: Wessex Astrologer, 2009). One should note that the prefix "Primary" was invented in the early modern period to differentiate the technique from the "Secondary Directions" invented by Pladidus. "Primary" here partly refers to the fact that the Directions are based on the primary motion, that is, the apparent motion of the skies around the Earth each day, or, in astronomical terms, the Earth's rotation around its own axis. Thus, the technique is often referred to simply as "Directions." I have retained the fuller nomenclature for the sake of clarity. Claudius Ptolemy gives a description of the procedure in Tetr. III 11 (Hübner) or III 10 (Robbins). Ibn 'Ezrā describes the method in his Book of Reasons (Seper hațTé 'àmîm, first version) X 3; see Shlomo Sela, Abraham Ibn Ezra. The Book of Reasons: A Parallel Hebrew-English Critical Editions of the Two Versions of the Text (Boston: Brill, 2007), 96-97. Ibn 'Ezrā here uses the term nîhûgîm (a noun formed from the above-mentioned root $n h g$, "to lead") to refer to Directions. He also discusses Directions extensively (especially its use in predicting lifespans) in various places in his Book of Nativities (Seper hamMôlādôt). See the edition and translation in Shlomo Sela, Abraham Ibn Ezra on Nativities and Continuous Horoscopy: A Parallel HebrewEnglish Critical Edition of the Book of Nativities and the Book of Revolutions (Boston: Brill, 2014). Again, the root $n h g$ is used to refer to Primary Directions.

14 Right Ascension is the measurement of the Earth's rotation around its own axis, that is, along the terrestrial equator. This means that, from the astrological perspective, it is a measurement of the motion of the celestial equator (the projection of the terrestrial equator into space) across the sky.

15 For explanations of the terms (öpla), see, e.g., James H. Holden, A History of Horoscopic Astrology: From the Babylonian Period to the Modern Age (2nd ed.; Tempe: American Federation of Astrologers, 2006), 92-93. 
as linhog 'èt hamma'ălôt 'al haggébûlîn ("to lead/direct the degrees [lit. 'risings'] along the bounds [that is, terms]"), in a passage that actually defines astrologers as those who are able to carry out this procedure. In other words, Ibn 'Ezrā presents Primary Directions as the very definition of what an astrologer does, which says something of the importance of the technique in Rashi's times. ${ }^{16}$ Other important parts of the practice of Primary Directions are to look at the directions of planets (in the astrological sense, the seven classical planets including the Sun and the Moon) and their aspects to important points in the base horoscope (again, the Ascendant being one of the most important such points). When directing planets to each other, the method becomes quite mathematically complex, being based on spherical trigonometry and so-called proportional semiarcs, a technique described by Claudius Ptolemy.

I will argue that the above is the technique that is referenced in Rashi's text.

\section{E RASHI'S CHOICE OF TERMINOLOGY AND POSSIBLE REFERENCES TO DIRECTIONS: TWO IMPORTANT EXPRESSIONS}

Returning to Rashi's commentary on v. 15:5, I would like to point to a number of conspicuous expressions and pieces of terminology that may suggest a connection with this specific form of astrological prognostication.

The first of these is the phrase șèe mē iștagnînut šellěk $\bar{a}$ (provisionally translated as "Go out from your astral divination"). The simple reading of this statement would be that YHWH is just commanding Abram to stop caring about his horoscope. However, on closer inspection, this makes little sense in the context. If the point were only for the protagonist to stop giving attention to astral divination, why, then, would it be so important for YHWH to state that the mazzāl ("stellar position") would change? The latter statement would rather undercut the point. Rather, Rashi's passage seems to imply that something astrologically important is going to happen in connection with the changing of Abram's and Sarai's names (leading to the birth of a son and subsequently, an entire people).

\footnotetext{
${ }^{16}$ The quotation from Ibn 'Ezrā is from his long commentary on Dan 2:2, which refers to the "Chaldeans" as hakmê hammazzālot ("the wise ones of the stellar positions," meaning "astrologers") and defines them as those who are able to direct degrees through terms and to planetary aspects. They are also said to be able to cast horoscopes for "revolutions" (solar and lunar return charts and charts for days and weeks). The Hebrew text of the quotation can be found in Sela, Abraham Ibn Ezra on Nativities and Continuous Horoscopy, 6 (my translation above is similar to Sela's, though not totally identical). One may note with some interest, though, that Ibn 'Ezrā does not provide an astrological interpretation of Gen 15:5 in his Genesis commentary. Indeed, he says nothing specifically about that verse at all.
} 
The point, then, is not that the iștagninût is unimportant and should be ignored, but that it has been altered in some way due to divine command.

Therefore, Rashi's point that YHWH ordered Abram to "go out" from his 'iștagninût suggests that this is somehow a reference to that alteration. It should be noted here that the exact meaning of 'istagninût is not wholly clear. It is often regarded as meaning "astral divination" or "astrology" in general (and in the above-mentioned text bBava Batra 16b, this is certainly the case, as it says that Abraham had 'iștagnînut "in his heart," which is a reference to his knowledge of astrology). The most probable etymology of the word is to regard it as originating in a sort of "root-ification" of a borrowing from Latin signum ("[astrological] sign"), which root then forms a sort of Aramaic-style 'itpěil abstract noun. Thus, literally and etymologically, the word would be the equivalent of something like "astro-sign-ification." ${ }^{\prime 7}$ It is quite possible simply to interpret this to mean "astrology" generally, but the connection to "sign" should not be ignored. It could also be argued that, at some point, this word could have signified the specific astrological technique having the risings of the signs across the horizon as one of its central issues. It seems that the word probably meant - at least at some point - "sign" or "sign study." The interpretation of 'iștagnînût as meaning "sign" was, in fact, argued by Jeffrey L. Rubenstein in his article on Talmudic astrology, in which the word is translated as "astrological sign"18 (see also the scholars mentioned in footnote 17 for other examples of the same view). Rubinstein comments that the Talmudic text seems to identify the counting of the stars with looking at Abra(ha)m's astrological sign. Thus, to make sense of the term 'iștagnînut, we must regard it as meaning not either "astrology" or "sign," but both, that is, "sign (-study)." In another place (his commentary on the above-mentioned bBava Batra 16b), Rashi defines 'îștagninût as hôzzeh bakkôkābim, "watching the stars," but one should note that this is when mentioning that Abraham was especially good at this. The word in that case definitely refers to a skill or activity, which means that it does not invalidate the possibility of the interpretation "sign(-study)" on Rashi's part.

What, then, can this mean for the interpretation of șe me'iștagninut šellěk $\bar{a}$, "go out from your 'iștagnînût"? What would that mean if we consider the possibility that this could be read as a reference to some form of astrological

17 Jastrow, Dictionary, 90 (s.v. 'istagnînût, using the spelling with sāmek) defines the word as both "astrological speculation" and as "planetary constellation." See also Francis Schmidt, "Le mazzal et le mérite, du 'Testament d'Abraham' à Rabbi Aqiba,"

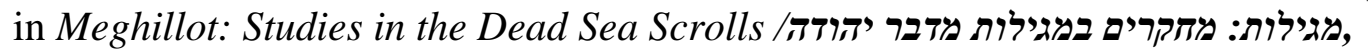

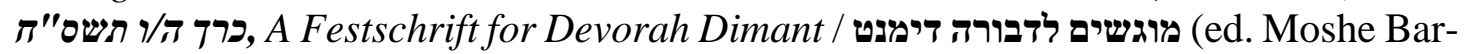
Asher and Emanuel Tov; Jerusalem: Mosad Bialik, 2007), 107, n. 11, which translates the word as "signe astral" and mentions the signum (Heb. signôn) etymology (as does Jastrow, Dictionary, 89, s.v. 'isțagnên).

18 Jeffrey L. Rubenstein, “Talmudic Astrology: Bavli Šabbat 156a-b,” Hebrew Union College Annual 78 (2007), 130. 
technique? Again, it is hardly just a case of leaving astrological speculation behind, as the text goes on to describe further astrological data. As we have seen, merely interpreting the expression as a repudiation of Abram's astrological divination makes little sense in the context. Rather, we should look for a meaning that actually gives meaning to "going out from the sign(-study)." It is here that I believe that the technique of Primary Direction is a good candidate for what Rashi intends to convey subtextually, that is, what he wants knowledgeable readers to associate with his words. Abram has studied his natal horoscope, but if he directs the degrees passing over the Ascendant ("going out from his sign") he will find something new. ${ }^{19} \mathrm{He}$ is not to stay with the astrological sign analysis that he knows but is exhorted to "move" from it, so to speak.

The next interesting expression is the statement that the "star position will be changed" (wěyištanneh hammazzāl). One important question here is the exact meaning of mazzāl. This term is famous for its bivalence, in a way that is similar to what we saw above concerning 'istagninut. The original meaning, derived from Akkadian manzaltu, is "stellar position," but this is often used metonymically to mean "fate" or "destiny" more generally. Rashi himself appears to use it in this wider sense in his commentary to Gen 30:11, where he elucidates the expression $b \bar{a}$ ' ga $\bar{a} d$ ("luck has come") as meaning $b \bar{a}$ ' mazzāl tôb ("a good mazzāl has come"). However, one should remember that the collocation mazzāl țôb was itself a set phrase meaning "good luck," meaning that the literal meaning "stellar position" for mazzāl is quite probably present in Rashi's language in other instances (especially in the context of astral speculation, as in the case of Gen 15:5). Additionally, as the context in Gen 30:11 is that of the birth of a son $(\mathrm{Gad})$, one should not discount the possibility that Rashi is thinking of a birth horoscope - a "good stellar position," quite literally - in that case, as well.

On the surface, one could argue that weyištanneh hammazzāl is simply a reference to the "rebirth" of the main characters as Abraham and Sarah as opposed to Abram and Sarai - meaning that these new identities would, effectively, possess new birth horoscopes. This, indeed, may be part of the underlying idea, effectively implying an instance of catarchic or elective astrology, in which the moment of starting an action is regarded as the "birth" of that event (cf. in a way, the possible interpretation of the "good stellar positions" at Gad's birth). The "astrological birth" of Sarah and Abraham would then

19 Note that, in pre-modern astrological sources, the terminology used is always that the Ascendant is directed to the following terms, signs, and aspects, not the other way around, as if the Ascendant were "sinking down" when the stars rise across it. This would fit well with the "go out from your sign" expression; the Ascendant moves away from its natal point. 
represent a sort of mix between the traditional disciplines of natal and catarchic horoscopy. ${ }^{20}$

If we combine this with the "go out" reference, Primary Directions really do stand out as an overarching interpretive reference for the passage. What the astrologer does when he/she directs the Ascendant of a native's horoscope is, in fact, "going out/going forth" from the original position of the Ascendant, as the years of the native pass by. As this happens, the "stellar position" is indeed "changed," as the Ascendant shifts between terms and signs. Thus, șe' mē iștagnînût šellĕkā [...] wěyištanneh hammazzāl would actually be a very good formulation of an exhortation to practice Primary Directions.

However, this is not all, as we shall see later in this article. The references to Abram being brought out of the "space of the world" and "looking down" may hold such references, too. Before discussing those expressions, we shall study in detail the background and textual history of the command to "go out from your sign," and see if Rashi's use of his sources has implications for the present line of inquiry.

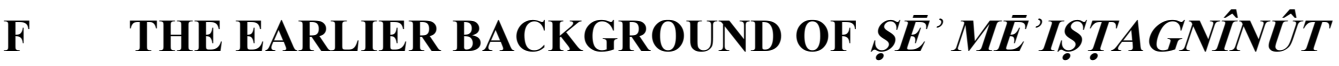

The original locus of the șe' $m \bar{e}$ 'iștagnînut expression is neither Rashi nor the Midrashim, but rather, as mentioned earlier, the Babylonian Talmud (Shabbat $156 \mathrm{a}-\mathrm{b}$ ), which uses this phrase but then explicitly states the later common view that astrological prediction as such did not apply to the Israelite people. We shall now look at this passage in greater detail and compare it to the version later synthesised by Rashi from his various sources: ${ }^{21}$

Wè āp rab sěbar 'ên mazzāl lĕyiśrā'èl, dè ămar rab yěhûdâ 'ămar rab minayîn še'ên mazzāl lěyiśrā'èl? šene'ěmar, wayyōṣè' 'ôtô hahûsâa. 'āmar 'abrāhām lipnê haqqādôš bārûk hû' ribbônô šel 'ôlām bēn bêtî yôrēš 'ôtî. 'āmar lô l'o kî̀ 'im 'ăšer yēșè mimme êk $k \bar{a}$. 'āmar lěpānayw ribbônô šel 'ôlām nistakkaltî bĕ iștagnînût šellî wĕ ênî rā'ûy lěhôlîd bēn. 'ămar lêh șe 'mè iștagnînût šellĕkā še'ên mazzāl

20 This seems to be the stance taken in the Gûr Aryeh commentary (1578), which explicitly says that the "changing of the star position" is due to the change of the names of the protagonists (wěyištanneh hammazzāl 'al yĕdê šinnnûy haššēm, "and the star position will be changed on account of the change of the name"). The text is available at Alhatorah.org, mg.alhatorah.org.

21 Concerning bShabbat 156a (and 156b) and its view of astrology, see also the abovementioned Gardner, "Astrology in the Talmud" and Rubenstein, "Talmudic Astrology." The latter translates the term mazzāl simply as "planet" (in the astrological sense, including the Sun and Moon; see Rubenstein, "Talmudic Astrology," 11). I have chosen a more general "star position," which fits with the origin of the word in Akkadian manzaltu ("position"). Rubenstein generally deals with the structure and editing of the Talmudic passage and on the situatedness of its ideology within the astrological climate of Sasanian Persia. 
lěyiśrā'èl. Mā'y da'tekā? Děqā'î ședeq bĕma ‘̆ărāb? Děmahdarnā' ûmôqîmna ${ }^{\prime 22}$ lêh běmizrāh, wěhaynû diktîb mî hē î̀r mimmizrāh ședeq yiqrā'èhû lěraglô.

And also, Rav was of the opinion that there is no star position for Israel, for Rav Yehuda said that Rav said: "Whence [do we know] that there is no star position for Israel? As it is said: 'and he brought him outside': Abraham said before the Holy One Blessed Be He: 'Lord of the World, a son of my house will inherit me', and he answered him: 'No, but one who will proceed from your innards.' [Abraham] said before him: 'Lord of the World, I have considered my astrology/sign, and I am not seen to father a son.' [God] said to him: 'Depart from you astrology/sign, for there is no star position for Israel. What are you thinking? [Is it] because Jupiter [sedeq] stands in the west [in your horoscope]? Then, I will return it and put it in the east, and that is why it is written: 'Who awakened righteousness [ședeq] and calls it to his feet?' [Isa 41:2].

In the Talmudic passage above, it is clear that YHWH is regarded as having power over astrological prediction for Abraham and his heirs, and that he demands that Abram cease his astrological theorising and analysis. He makes a point of being able to move Jupiter into what is probably a reference to the cusp of the First House/the Ascendant/the horizon (east) ${ }^{23}$ of Abraham's horoscope at

22 The standard reading is mwqmyn', which is somewhat morphologically anomalous for Babylonian Aramaic, with the yôdh after the second mêm rather than the qôph, which would be the normal causative participle form with a subject suffix. I have regularised the reading above (cf. Yitzhak Frank, Grammar for Gemara and Targum Onkelos: An Introduction to Aramaic (Jerusalem: Ariel United Israel Institutes, 2003), 133 and Bar-Asher Siegal, Introduction to the Grammar of Jewish Babylonian Aramaic, 139,311 . This morphologically regular reading is, in fact found in one of best manuscripts of the passage, MS Bodleian Opp. Add. fol. 23 (Neubauer 366); I give a standard-type vocalisation above, but early vocalised manuscripts suggest that the actual pronunciation was an uncontracted mawqimna. Heartfelt thanks to Matthew Morgenstern for providing this information on the Bodleian manuscript and the vocalisation (pers. comm, email December 17th, 2020).

Another attested reading is the regular môqëmînan ("we [will] establish"), found in the 1520 Venice (Bomberg) edition, which only differs from the standard text by substituting a nûn for the final 'àleph.

23 Theoretically, the mention of Jupiter standing in the west and being moved to the east could also be interpreted as a reference to the concept of a planet being oriental or occidental, that is, being placed to the east or the west of the Sun and thereby being visible in the west (if east of the Sun and thereby setting after it) or in the east (if west of the Sun, and thereby rising before it) - a concept that was highly important in Hellenistic astrology. However, I would say that the use of the Aramaic verb qwm ("stand") more likely suggests a placement in the mundane sphere, that is, a house placement. Moving a planet from one side of the horoscope to the other (from the Descendant to the Ascendant) seems more rhetorically effective than moving it to the 
will (reinterpreting an original Deutero-Isaianic reference to Cyrus as sedeq, which is also the name of Jupiter).$^{24}$ One may also note with some interest how it quotes the book of Isaiah (41:2) at the end, appearing to equate the horizon/Ascendant with the "feet" of God! ${ }^{25}$ I would like to suggest that this is due to the persistent astrological tradition of associating the Twelfth House (the one into which a planet rises after crossing the horizon/Ascendant) with the feet of a native of querent. When Jupiter is in the east, on the Ascendant, it is just on the way from the First House into the Twelfth (the feet). ${ }^{26}$

Let us now observe how Rashi uses this passage. He keeps șe $\bar{e}^{\prime}$ mè iștagninût šellěkā, but interestingly neglects to quote 'ên mazzāl lèyiśrà'èl. Since that seems to be the main point towards which the Talmudic passage is

other side of the Sun. Howsoever the matter may originally have been, Rashi may have read it as a house reference, as I argue further on.

24 Rubenstein "Talmudic Astrology," 130 argues that the Talmudic passage does not imply an outright rejection of the efficacy of astrology but the power of God to use his miraculous powers to overrule human astrological speculation. I agree with this analysis.

25 Interestingly, in Rashi's own comment to this Talmudic passage, he states that Jupiter is actually Abra(ha)m's own star (mazzāl). Could this be a reference to the Ascendant ruler, or to the "ruler of the chart," a much-disputed concept in pre-modern astrology? In any case, he there interprets the references to east and west in what seems to be a more geographical manner, referring to the west as a cold place and to the east as a hot one, This, however, is also a type of directional association occurring in astrological sources. See, for example, Claudius Ptolemy, Tetr. I 11 (Hübner)/I 10 (Robbins) - there, it is argued that the east is dry and the west is moist. Thus, nothing precludes Rashi reading this as a reference to astrological houses when composing his Torah commentary.

26 The association between the Twelfth House and feet is presumably extrapolated from the (as it appears, older) linking of the signs to various body parts (beginning with Aries for the head and ending with Pisces for the feet). As the "ideal original horoscope" has Aries rising - being the first sign in the traditional reckoning - and the other signs then following suit with one house each, the feet end up in House 12. This principle (and the reference to feet for the Twelfth House) is stated outright in the 17th century classic of English astrology, William Lilly, Christian Astrology, book I, chapter 7. It does not appear in early Greco-Roman authors such as Valens, Firmicus or Paulus Alexandrinus, but it is mentioned in early texts of classical Indian astrology (which is descended from Hellenistic astrology). The connection between the houses and body parts appears in Yavanajātaka 5.16 and Brhajjātaka 5.23. This suggests that the principle was there in Hellenistic tradition, too. In Mediaeval Perso-Arabic astrology, a seeming trace of the doctrine can be found in the writings of the ninth century CE astrologer Abū Bakr. See Benjamin Dykes, Persian Nativities. Volume II: 'Umar alTabarī \& Abü Bakr (Minneapolis: Cazimi Press, 2010), 257-258, where it is stated that a malefic planet (i.e. Mars or Saturn) together with the First House ruler in the Twelfth House (or the First House ruler in the Twelfth aspected by a malefic by square or opposition) leads to a chronic foot ailment. 
moving, this is an interesting pretermission indeed. To be sure, this is an argumentum e silentio, but not an uninteresting one. Rashi in effect acts as a biblical redactor here, keeping some things and disregarding others; and his choice of what to keep and what to discard says something about the picture that he wants to paint. In essence, this becomes a question of redaction criticism.

As we have seen, another fact clearly points to a total disavowal of astrology not being Rashi's intention in excerpting these texts: if it were so, the reference to "changing the star position" would be rather pointless. ${ }^{27}$ The idea that Abraham and Sarah would have a different future than Abram and Sarai is predicated on the relevant horoscope being significant. As mentioned, Rashi seems to read the exhortation to "go out" or "depart" from Abram's 'iștagnînut not as an order to ignore astral divination, but to change one's view and/or interpretation thereof, or, in fact, to direct the Ascendant with the primary motion. The talk of Abram not being an 'astrôlôgôs but a prophet is wholly missing in Rashi's text, which is quite fitting, given that Rashi actually provides an astrological solution to Abram's problem. This implies that Rashi has subtly changed or adapted the message of the passages that he used as the basis of his interpretation.

Another fact that may have helped Rashi to read 'iștagninût šellěka as "your sign" as opposed to simply "astral divination" in general is the presence of šellěka ("your"). To be sure, this word was there in the Talmudic source, but the "individualising" expression may well have served as a helping factor in the re-interpretation. It would not be a matter, then, of "any old sign," but of Abram's sign in a very personal sense (Rashi's interpretation of Jupiter in the Talmudic passage as Abram's "personal star" - see footnote 25 - would fit well with such an individualised reading on the commentator's part).

Given the possible interpretation above of 'iștagninût as "sign," one could wonder whether bShabbat $156 \mathrm{a}-\mathrm{b}$ is itself intended to include a reference to Primary Directions. This is, of course, a possibility, though we know too little of the actual practice of Jewish astrology at such an early period to make a choice either way. Further, 'ên mazzāl lěyiśr is less amenable to such an interpretation. However, the implication of God moving Jupiter from the Descendant to the Ascendant could actually be interpreted as such a reference. We should note that in the biblical text, Abra(ha)m himself objects to the possibility that a man of a hundred years would engender a son (Gen 17:17), an age that would imply a massive change in stellar position in Primary Direction. This reads in an interesting way in relation to the

27 Theoretically, it could be argued that Rashi summarises the Talmudic idea that God is moving Jupiter from one side of the horoscope to the other (thus "overruling" astrology), but even then, the gist would not be a complete disavowal of its efficacy as such. For an example of an attitude similar to this, see the disquisition on the views of Abraham bar Hiyya later in this article. 
Talmudic passage. One could imagine the Talmudic scholars having an idea of Jupiter moving from the Descendant to the Ascendant using the primary motion. To be sure, 100 years is not nearly enough for a planet to move from one celestial quadrant in Primary Direction to the opposite one in non-extreme geographical locations. In the idealised case of the signs rising at a uniform speed, if one is born on the equator, ${ }^{28}$ or if the planet one is plotting is on one of the equinoctial points, this would mean (around) 180 years, as Primary Directions traditionally equate one degree of Right Ascension with one year of life. However, the language could be interpreted as referring to the primary motion moving Jupiter, albeit with a miraculous "push" by YHWH himself. ${ }^{29}$ Regardless of whether that was originally what was intended in the Talmudic passage, one might well imagine that this is how Rashi reads it in the context of his own interpretation.

An even more interesting - though speculative - possibility would be Rashi reading the Talmudic reference to moving Jupiter from the West to the East not based on astrological calculations fitting Palestinian or Babylonian geography but in the light of the latitude at which he himself was living (Troyes in modern France). That is, it is far enough north of the equator to allow the possibility of a planet on the Descendant taking only about 120 years to move to the Ascendant in Primary Direction (viz., given the idealised case of a native being born with the exact beginning of tropical Capricorn on the Ascendant). ${ }^{30}$ Thus, if Rashi knew something of Primary Directions in his own milieu, the moving Jupiter providing an heir in the Talmudic passage may have seemed less of a miracle. This could thus suggest not only a knowledge of the technique itself but also a reflection of Rashi's own geographic situation as a basis for his interpretation.

\section{G ASPECTS AND GAZES}

At the end of Rashi's exegesis of Genesis 15:5, there is additional "loaded vocabulary" that may be relevant in the present context. This consists of the statement that another possible interpretation (based on Genesis Rabbah) is hộ̣̂̂̀ mẹhălālô šel 'ôlām wěhigbîhô lěma lâ min hakkôkābîm wězehû lěšôn habbäțâ milěma lâ lěmatțâ ("he brought him out from the space of the world and

28 Even at the equator, there is a slight deviation in ascensional time due to the Earth's axial tilt, but generally, it may be said that it would take a planet very close to 12 hours (=180 degrees of Right Ascension movement) to move from the Descendant to the Ascendant in such a case.

29 That a sort of miraculous power of YHWH is the point of the tale is emphasised in the original story as well. As Walter Brueggemann, Genesis (Louisville: Westminster John Knox, 2010), 144 puts it as, "[t]he same God who makes stars without number can also make a son for this barren family."

30 I would like to thank Martin Gansten for suggesting this theoretical astrological configuration for Rashi's physical location and the 120 years it would imply for the motion in Primary Direction. 
brought him up on high above the stars - and [the expression "looking"] refers to looking from above down below"). Again, on the face of it, this seems to be a reference only to Abram being lifted above the stars, to show that he is not under their sway. ${ }^{31}$ However, the term habbāt $t a$ is quite interesting; this (or, rather, the verbal root $n b t$, "look, gaze," generally) happens to be the term used in Mediaeval Hebrew literature for astrological aspects. ${ }^{32}$ This root occurs in the biblical text itself, but its persistence here may carry deeper import. The combination between this word and the reference to the hălälô šel 'ôläm ("the space of the world" or even "the orb of the world"33) is conspicuous. In the Midrashic source, Abram is said to have been shown the "places" of the sky, which may imply a reference to the astrological houses or "places" ( $\tau$ ó $\pi \mathrm{o}$ ) that make up the mundane sphere (see footnote 11 above), and could have made Rashi think of astrological Directions, aspects and influences. In the context delineated here, the wording involving "the orb of the world" makes one think of an astrological aspect that Abram is made to "view." The text implies that he is brought up above the orb of the heavens, seeing the primary motion (that is, in modern terms, the earth revolving around its axis) in action, and thus, the various aspects appearing in a Primary Direction appearing and giving their effects. These combined references thus, paint Abram as a supreme "knower of the stars" by associating him with terminology reminiscent of that most technical and highly regarded of astrological techniques. ${ }^{34}$ Given that Rashi repeats Genesis

31 Such an interpretation of the lifting above the firmament is, in fact, represented in the so-called Midrash Aggadah of Solomon Buber (based on a Mediaeval manuscript from Aleppo), which explicitly says (ad loc.) that although most humans are "under their constellation" (běnê 'ādām tahat mazzālām) which "therefore judges them" (lëpîkāk hammazzāl dān 'ôtām), Abra(ha)m is "above the dome of the firmament, in which the constellations are" (lěma lâ mikkîppat hārāqîa' šehammazzāl šām), and therefore, presumably, exempt from astrological influence. The text is available from Alhatorah.org, mg.alhatorah.org.

32 In the above-mentioned passage from Ibn 'Ezrā's long Daniel commentary, for example, the nominal derivation mabbāt ("gaze") is used for "aspect." The use of words that mean "looking" or "gazing" in this context is a constant in the history of astral divination and astrology, for example, in Babylonia. Already in the Enuma Elish, the verb natâlu ("to look, behold") is used of the Sun and the Moon in opposition in tablet V, line 19, and the Latin expression aspectus literally means "gaze." The Enuma Elish line says of the moon: i[n] üma Šamaš ina išid šamê ina[țal]uka, "when the Sun beholds you from the base of heaven [=the horizon]..." The text is available in Wilfred G. Lambert, Babylonian Creation Myths (Winona Lake: Eisenbrauns, 2013).

33 The Sefaria translation renders hălālô šel 'ôlām here as "the terrestrial sphere." The translation can be found online at www.sefaria.org/Rashi_on_Genesis.15.5?lang=bi.

34 On the technicality of Primary Directions, note especially how the 10th-11th century writer al-Bīrūnī almost abjectly refers to Directions between zodiacal points that are not rising or culminating as "a long and difficult business," as it is performed using the calculation of proportional semi-arcs of motion. Al-Bīrūn̄i, The Book of Instruction in the Elements of the Art of Astrology (trans. R. Ramsay Wright; London: 
Rabbah's point that the reference is to a habbățâ miléma 'lâ lěmatțâ ("looking from above down below"), one can envision the imagery of a benefic astrological aspect meeting the Ascendant in a Primary Direction (either from above or literally from the sky down "below" to the horizon).

It is also notable that Genesis Rabbah, which in all probability was one of Rashi's sources, uses the interesting expression hammazzāl dōhẹqqēn ("the star position oppresses me"), which seems to express a sort of temporally shifting nature of the problem - or at least makes such a reading possible. Stating that one is (temporarily) "oppressed" by a star sign or astrological position would make great sense in the context of Primary Directions, in which the signs, in fact, do move across the Ascendant over time. Thus, it may well have been read by Rashi.

\section{H INITIAL SUMMARY}

Thus far, we have seen the following points that suggest a reference to Primary Directions in Rashi's reading of Gen 15:5:

- The exhortation to "go out from your sign," but with the original and accompanying Talmudic point that there is no "star position for Israel" conspicuously removed. The point about Abram not being an 'astrôlôgôs is also missing from Rashi's commentary. These two are weighty theologicalideological points, and their removal in Rashi's exegesis seems intentional and important.

- The statement that the "stellar position will be changed."

- The conscious choice of the description of Abram being lifted out of the orb of the world (thereby viewing its motion) and "gazing" (root $n b t$, the same root used for astrological aspects) downwards. The talk of the "places" of the heavens in Rashi's sources may also point in this direction.

- Rashi's Talmudic source discussing the position of Jupiter shifting from the Descendant to the Ascendant and the ability on God's part of making that planet move from the one to the other, in a way that would make sense in terms of Primary Directions in the place where Rashi lived (but not in Palestine or, for that matter, Babylonia).

One could perhaps object methodologically to my seeing the removal of the negations of astrology as important and intentional on Rashi's part while I at the same time view the Midrashic and Talmudic arguments about "places" and Jupiter as possible points of inspiration for Rashi even though he does not quote them. To this, I would answer that these represent two very different categories

Luzac and Co., 1934), 382-383, also quoted in Gansten, "Balbillus and the Method of Aphesis," 590. 
of statements. The first one is a theological/ideological statement of world-view: should Jews engage in astrology at all, and does it have any efficacy for them? The other has to do with astrological/astronomical detail and not with the whole question of the be or be-not of astrology. Thus, I find it defensible to view Rashi's treatment of them in a somewhat different light - as conscious omissions in the former case and as possible (but unstated) "environments of interpretation" in the latter.

\section{RASHI'S READING AND THE HISTORICAL BACKGROUND OF THE TEXT}

Thus, it seems likely that Rashi's commentary includes a reference to astrological technique, specifically Primary Directions. The question then is: how does this reading relate to the original text on which he was commenting? As mentioned at the beginning, I do not believe that the author of Gen 15:5 was thinking of Abraham carrying out any specific astrological technique. Indeed, it is unlikely that the original text even includes a reference to "astrology" as commonly understood. However, I do consider it highly probable that some reference to the older motif of knowing the wisdom of the stars, so to speak, was intended (cf. both the Ugaritic material mentioned at the beginning and the traditions about "Chaldea") and that the early Jewish exegetical tradition picked up on this, injecting the idea of Abraham as an actual astrologer into that preexisting material. It is this, snowball-like tradition, I argue, that Rashi expanded upon. From a historical-critical perspective, one can say that the Genesis text grew out of a tradition about wise people knowing the stars. Rashi's perspective, however, was of course not historical-critical but based on (a) the Rabbinic exegetical tradition to which he was accustomed, which painted Abraham as an actual astrologer, and (b) the contemporary astrological practices of his day. Thus, the reading he arrives at (and which I have tried to elucidate above) is in effect created through a super-imposition of later hermeneutical tradition onto the sketchy "wisdom of the stars" associations actually present in the original text, and deriving from earlier ancient Near Eastern sources. ${ }^{35}$

35 An anonymous reviewer posits the question of whether Rashi's interpretation here is "descriptive or prescriptive," that is, did Rashi find something in the text that was actually there, so to speak, or did he impose his own reading on the text? To this I would thus answer that he did certainly impose his own understanding based on earlier Rabbinic exegesis, which he creatively altered according to the astrological practices of his time. However, this Rabbinic and Early Jewish tradition about Abraham as an astrologer did not turn up out of nowhere but was built on the idea of wise characters knowing the ways of the stars (and especially Chaldeans doing so) which were present when the text was originally written. Therefore, I would say: yes, Rashi imposed the ideas of his time (specifically, as I argue, references to Primary Directions and perhaps electional horoscopes). Nonetheless, the fact that he was motivated to do so is a function 
Wikander, "Go out from Your Sign,” OTE 33/3 (2020): 556-581 575

Given the importance of Rashi's contemporary milieu for the understanding of why his commentary looks the way it does, we shall now move on to a comparative discussion of an author illustrating that milieu in a way relevant to the question of Abraham as an astrologer.

\section{J A PARALLEL: ABRAHAM BAR ḤIYYA}

One interesting and illuminating piece of comparative material from the same period discussing Gen 15:5 in astrological terms can be found in Abraham bar Hiyya (ca. 1065-1140 CE), an author contemporary with Rashi, and indeed probably the first Hebrew-language writer on astrology. Bar Hiyya explicitly mentions the same biblical verse as the one here under discussion. He mentions Abraham as a great astrologer and he is known to have had Primary Directions as part of his "astrological tool-bag." Most importantly, he mentions the verse in question as an argument for astrology rather than for its repudiation. He thus appears to espouse certain similar ideas as that which I propose here for Rashi, which makes it interesting to consider his views in some detail. ${ }^{36}$

As an astrological writer, Abraham bar Hiyya is interesting from many perspectives. His writings include Astrological History, a general text on astrological calculation (called Hešbôn Mahlěkôt Hakkôkābîm, "The Calculation of the Motion of the Stars"), which covers both annual horoscopy ("revolutions") and Primary Directions (which he refers to as tahălûkôt hakkôkābîm) - and a Letter to Yehuda ben Barzillai, in which he defends the practice of astrology against various objections. It is in this text that he mentions our verse.

Below is what Abraham bar Hiyya writes in his Letter to Yehudah ben Barzillai: ${ }^{37}$

not only of his time but also of an earlier tradition that has a sort of (very sketchy) basis in the Genesis text itself. Again, the snowball image is quite apt here.

36 On Abraham bar Hiyya's astrology, see Shlomo Sela, "Abraham Bar Hiyya's Astrological Work and Thought," Jewish Studies Quarterly 13 (2006), 137-138; my dating of Bar Hiyya's follows his. Note that the technique of Bar Hiyya's that Sela renders as "processions of the planets", is actually a reference to Primary Directions, even though Sela does not use that term for the procedure. Sela refers the reader to the relevant parts of Ptolemy's Tetrabiblos for details, specifically, the parts which deal, unsurprisingly, with the technique of Primary Directions as applied to the hyleg (known as aphetēs in Greek), or the planet or point signifying the length of a native's life. The discussion of the șè mè iștagnînut šellěkā expression can be found in the article, Sela, "Abraham Bar Hiyya's Astrological Work and Thought," 142.

37 The text follows the edition in Zechariah Schwartz, "אגרת ר' אברהם ב"ר חייא הנשיא שכתב לרי יהודה ב"ר ברזילי על שאלה בכלדיים" in Festschrift Adolf Schwartz zum siebzigsten Geburtstage 15 Juli 1916 (ed. Samuel Kraus; Berlin \& Wien: R. Löwit, 1917), 27 (Hebrew section). 
Wěnir'eh mimmennû šehokmat mahălkôt hakkôkābîm hokmat 'ěmet ûrě ûyâ lěhahăzîq bāh, wělilmôd 'ôtāh mippěnê šehaqqādôš bārûk hû' 'āmar lě abrāhām 'ābînu: șề mè'istagnînût šellěkā še'ên mazzāl lěyiśrā'èl, wělō' 'àmar lô șè mē'iștagnînût še ênāh hokmâ wĕlō'

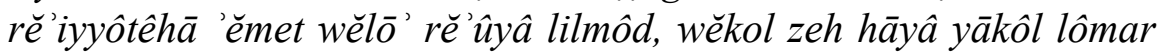
'èlāyw 'im lo' hāyĕtâ hokmâ zo't rě ûyâ lěhahăzî̀ bāh wĕlilmôd 'ôtāh, wĕtihyeh mikkā'n hokmat hakkôkābîm qěrûyâ hokmâ ûrĕ'iyyiôtêhā 'ěmet ûrĕ' ûyâ lidrôš wĕlilmôd. Wěyākôl 'ôtāh liqrôt 'ôd

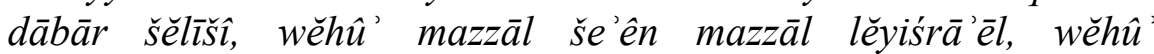
šehașạaddî̀im miyyiśrāèl yĕkôlîn lěbattēel mēălêhem gizrôt mahlěkôt hakkôkābîm běșidqātām ûbitpillātām mah še ên kēn bišs 'ar 'ûmmôt hā'ôlām...

And we see from this that the science of the motion of the stars is a true and worthy science to engage in and to study, from the fact that the Holy One Blessed Be He said to Our Father Abraham: "Go out from your sign/astral divination, for there is no constellation for Israel" but did not say to him: "Go out from your sign/astral divination, for it is no science, and its views are not true, and it is not worthy of study" - and all this [God] could have said to him if this science were not worthy of engaging in and studying; and from this, this science of the stars should [indeed] be called a science, its views true, worthy of pursuing and studying.

But one can read here yet a third thing, and this is the "constellation," that "there is no constellation for Israel": and this means that the righteous of Israel are able to nullify from themselves the patterns of the motions of the stars with their righteousness and their prayers, something which is not the case for the rest of the ethnicities of the world...

Abraham bar Hiyya shows that șé' mè iștagnînut was not necessarily interpreted as a repudiation of astrology in Rashi's day. In contradistinction to Rashi, he does include 'ên mazzāl lěyiśrā'è èl in his argument, but makes the point that the ethical and ritual merits of the Jewish people can counteract astrological influence. On a more uncertain note, and in line with the arguments put forth in this article, one may wonder if Primary Directions were on Abraham bar Hiyya's mind as well in the present case. It comes down to what, in this context, he means by "the motions of the stars" (mahlěkôt hakkôkābîm). Is this just a general reference to astral motion, as in the title of the above-mentioned work (which does, as mentioned, cover Primary Directions, among other things) or a similar subtextual reference to the tahălukkôt hakkôkābîm (Primary Directions themselves)? Note that the expressions are indeed quite similar, and one could even toy with the idea of a graphical confusion between the two. If some such reference is intended, one could argue that Abraham bar Hiyya provides additional circumstantial evidence for my interpretation both of 'iștagnînut and of the specific technique used to analyse it. 
Wikander, "Go out from Your Sign,” OTE 33/3 (2020): 556-581 577

\section{K READERSHIP, ASTROLOGICAL CONTEXT AND INTENTIONALITY}

If we return to Rashi, the commentator's choices, terms and omissions put together may well be regarded as having incited a contemporary Jewish and astrologically-versed reader of the Middle Ages to think of Primary Directions, and I think it is plausible that this is intentional. If one regards it probable that Rashi does intend a reference to certain specific astrological techniques, among them Primary Directions, the question then would be why he added this reference, and for what kind of readership it was intended. It must be noted that the references are quite subdued - they consist in certain "signal words" that would have made a knowledgeable reader think of Primary Directions, rather than outright descriptions. The reason for this mode of expression is less than an enigma. Astrology was, after all, sometimes frowned upon in Mediaeval Judaism (Maimonides was a well-known example of this attitude, though there were notable examples of the opposite one, like Masha'allāh, Ibn 'Ezrā, Gersonides, ${ }^{38}$ some Kabbalists, and the above-mentioned Abraham bar Hiyya). The reworking of the Talmudic text about there being no mazzāl for Israel is highly interesting in this regard. It appears as though Rashi is trying to rework the traditional accounts (Genesis Rabbah, bShabbat) in a way that seems less condemning towards astrological practice and allows for an association with electional astrology and Primary Directions.

Again, Rashi was more or less contemporary not only with Abraham bar Hiyya but also with Abraham Ibn 'Ezrā, for whom Primary Directions were quite central (and who also wrote a work on electional astrology, Seper HamMibhārîm), though it must be granted that he was not a contemporary of Ibn 'Ezrā's important astrological works, as Rashi died in 1105, when Ibn 'Ezrā was still a young man. It is worth mentioning that although Ibn 'Ezrā and Bar Hiyya were the first astrological authors known to have written in Hebrew, there were numerous earlier important Jewish astrologers such as Masha'allāh and Sahl ibn Bishr. Whether or not Rashi was aware of the teachings of these earlier writers (he does not appear to have had a command of Arabic, the language in which these authors wrote - at least not at that level), it is a fact that astrological tradition was part of the Jewish learned milieu. The existence of two contemporary Jewish authors propagating Primary Directions in Hebrew shows the existence of such a tradition in it.

As to the question of the plausibility of Rashi possessing enough astrological knowledge to make this sort of reference, one should note that the great commentator displays such knowledge in other places, for example when

38 On the astrology of Gersonides, see Shlomo Sela, "Gersonides' Astrology and Abraham Ibn Ezra," Aleph: Historical Studies in Science and Judaism 17 (2017): 250323. 
he alludes to the system of astrological planetary hour rulership in his exegeses of bBerakhot 59b, bShabbat 129b, and bEruvin 56a (in addition to the bShabbat passage discussed above). ${ }^{39}$ This means that acquaintance with astrological technique and concepts is definitely present. ${ }^{40}$ Moreover, Rashi's Genesis commentary itself gives testament to an acquaintance with astrological concepts. Already in his commentary to Gen 1:14, he seems to regard eclipses as portents of dangerous events, and he is aware ${ }^{41}$ of the actual length of the solar year (365.25 days) and defines the year outright as the passage ${ }^{42}$ through the twelve signs of the zodiac (for which he uses the irritatingly polyvalent term mazzāl yet again).

\section{CONCLUSION}

Going back to the question of the larger tradition in Northwest Semitic storytelling about wise "knowers of the stars," it is interesting to note that Pughat in the Ugaritic Aqhat story, who is described as such a character, is active in a story that has to do with the production of an heir and the guaranteeing of inheritance. This is the same type of paradigmatic telling that is applied to Abra(ha)m. I would argue that what Rashi is, in fact, doing is grounding this association more clearly in actual astrological techniques known in his time, specifically Primary Directions, the prognostic technique par excellence, that Rashi's contemporary Ibn 'Ezrā viewed as the very definition of astrological acumen. Even more alluring is the possibility that he applied astrological reasoning relevant to his own time and place to his reading of his sources. Thus,

39 See Reimund Leicht, "The Planets, the Jews and the Beginnings of "Jewish Astrology," in Continuity and Innovation in the Magical Tradition (ed. Gideon Bohak, Yuval Harari and Shaul Shaked; Leiden: Brill, 2011), 285. See also idem, "The Reception of Astrology in Medieval Ashkenazi Culture," Aleph: Historical Studies in Science and Judaism 13 (2013): 209-210, highlighting Rashi's use of astrological knowledge for elucidating Talmudic sources and his quoting a non-Rabbinic scientific source (the physician Shabbetai Donnolo) in one of these cases.

40 The older view that astrology was not really an issue for Jewish theology before the 13th century CE - reflected as a sort of commonplace in Manfred R. Lehmann's "New Light on Astrology in Qumran and the Talmud," Revue de Qumrân 8 (1975): 599-602 has been substantially challenged since (as in a sense it was by Lehmann himself). For example, Rubenstein, "Talmudic Astrology," 109-110 takes it for granted that astrology was a relatively mainstream interest in Jewish circles from early Rabbinic times and onwards. A similar view can be found in Gardner, "Astrology in the Talmud."

41 That is, according to one textual reading.

42 Of the Sun, though, interestingly, Rashi writes mahălěkān ("their passage"), as though talking of both the Sun and the Moon. This must be a reference to the Moon's continuous motion through the Zodiac each month, as it must be regarded as inconceivable that Rashi was unaware of what a month is. In addition, given that the biblical passage he is commenting on talks of the "two lights," it is understandable that he wants to bring the Moon into the equation, as well. 
in a way, Rashi applies his well-known interest in pěšat even here. Thus, an old tradition about interpretation of the meaning of the stars being important for securing offspring and inheritance is tied to concrete astrological practice from his own milieu - for those who had ears to hear with.

\section{BIBLIOGRAPHY}

Al-Bīrūnī. The Book of Instruction in the Elements of the Art of Astrology. Translated by R. Ramsay Wright. London: Luzac and Co., 1934.

Alhatorah.org. Cited 8 November 2020. Online: mg.alhatorah.org.

Bar-Asher Siegal, Elitzur A. Introduction to the Grammar of Jewish Babylonian Aramaic. Lehrbücher orientalischer Sprachen/Textbooks of Near Eastern Languages III/3. Münster: Ugarit-Verlag, 2013.

Barker, Margaret. The Mother of the Lord, Volume 1: The Lady in the Temple. London \& New York: Bloomsbury T\&T Clark, 2012.

Brueggemann, Walter. Genesis. Interpretation. Louisville: Westminster John Knox, 2010.

Dimant, Devorah. "Abraham the Astrologer at Qumran? Observations on PseudoJubilees (4Q225 2 I 3-8)." Pages 71-82 in Textual Criticism and Dead Sea Scroll Studies in Honour of Julio Trebolle Barrera: Florilegium Complutense. Edited by Andrés Piquer Otero and Pablo A. Torijano Morales. JSJSup 157. Leiden \& Boston: Brill, 2012.

Dykes, Benjamin, ed. and transl. Persian Nativities: Volume II: 'Umar al-Tabarī \& Abū Bakr. Minneapolis: Cazimi Press, 2010.

Frank, Yitzhak. Grammar for Gemara and Targum Onkelos: An Introduction to Aramaic. Jerusalem: Ariel United Israel Institutes, 2003.

Gansten, Martin. Primary Directions: Astrology's Old Master Technique. Bournemouth: Wessex Astrologer, 2009.

Gansten, Martin. "Balbillus and the Method of Aphesis." Greek, Roman and Byzantine Studies 52 (2012): 587-602.

Gardner, Gregg. "Astrology in the Talmud: An Analysis of Bavli Shabbat 156." Pages 314-338 in Heresy and Identity in Late Antiquity. Edited by Eduard Iricinschi and Holger M. Zellentin. Texts and Studies in Ancient Judaism 119. Tübingen: Mohr Siebeck, 2008.

Harari, Yuval. Jewish Magic before the Rise of Kabbalah. Translated by Batya Stein. Detroit: Wayne State University Press, 2017.

Herczeg, Rabbi Yisrael Isser Zvi et al., eds. The Sapirstein Edition: The Torah with Rashi's Commentary: Translated, Annotated, and Elucidated. Vol. 1 Bereishis/Genesis. Artscroll. New York: Mesorah Publications, 1995.

Holden, James H. A History of Horoscopic Astrology: From the Babylonian Period to the Modern Age. 2nd edition. Tempe: American Federation of Astrologers, 2006.

Hübner, Wolfgang (ed.). Claudii Ptolemaei opera quae exstant omnia, volume III 1: AПOTE 1 ЕMATIKA. Bibliotheca scriptorum Graecorum et Romanorum Teubneriana. Stutgardiae et Lipsiae: Teubner, 1998.

Jastrow, Marcus. A Dictionary of the Targumim, Talmud Babli and Yerushalmi, and the Midrashic Literature. Leipzig: W. Drugulin/Luzac/Putnam's Sons, 1903.

Lambert, Wilfred G. Babylonian Creation Myths. Mesopotamian Civilizations 16. Winona Lake: Eisenbrauns, 2013. 
Lehmann, Manfred R. "New Light on Astrology in Qumran and the Talmud." Revue de Qumrân 8 (1975): 599-602.

Leicht, Reimund. "The Planets, the Jews and the Beginning of 'Jewish Astrology'." Pages 271-288 in Continuity and Innovation in the Magical Tradition. Edited by Gideon Bohak, Yuval Harari and Shaul Shaked. Jerusalem Studies in Religion and Culture 15. Leiden: Brill, 2011.

Leicht, Reimund. "The Reception of Astrology in Medieval Ashkenazi Culture." Aleph: Historical Studies in Science and Judaism 13 (2013): 201-234.

Lilly, William. Christian Astrology: Book I. 2nd ed. John Macock: London, 1659.

Margalit, Baruch. The Ugaritic Poem of AQHT: Text, Translation, Commentary. BZAW 182. Berlin: De Gruyter, 1989.

Robbins, Frank E., ed. Ptolemy: Tetrabiblos. Loeb Classical Library. Greek Authors 435. Cambridge: Harvard University Press, 1940.

Rubenstein, Jeffrey L. "Talmudic Astrology: Bavli Šabbat 156a-b." Hebrew Union College Annual 78 (2007): 109-148.

Schmidt, Francis. "Le mazzal et le mérite, du 'Testament d'Abraham' à Rabbi Aqiba." Pages 101-118 in Meghillot: Studies in the Dead Sea Scrolls / מגילות: מחקקרים מוגשים /A Festschrift for Devorah Dimant כרך ה/ו תשס"ה ,במגילות מדבר יהודה לבורה Edited by Moshe Bar-Asher and Emanuel Tov. Jerusalem: Mosad Bialik, 2007.

Schwartz, Zechariah. שגרת ר' אברהם ב"ר חייא הנשיא שכתב לר' יהודה ב"ר ברזילי על שאלה" בכלדיים." Pages 23-36 in Festschrift Adolf Schwartz zum siebzigsten Geburtstage 15 Juli 1916. Edited by Samuel Kraus. Berlin \& Wien: R. Löwit, 1917.

Sefaria. Cited 8 November 2020. Online: www.sefaria.org.

Sela, Shlomo. "Abraham Bar Hiiyya's Astrological Work and Thought." Jewish Studies Quarterly 13 (2006): 128-158.

Sela, Shlomo. Abraham Ibn Ezra. The Book of Reasons: A Parallel Hebrew-English Critical Editions of the Two Versions of the Text. Études sur le judaïsme médiéval 35. Boston: Brill, 2007.

Sela, Shlomo. Abraham Ibn Ezra on Nativities and Continuous Horoscopy: A Parallel Hebrew-English Critical Edition of the Book of Nativities and the Book of Revolutions. Études sur le judaïsme medieval 59. Leiden: Brill, 2014.

Sela, Shlomo. "Gersonides' Astrology and Abraham Ibn Ezra." Aleph: Historical Studies in Science and Judaism 17 (2017): 250-323.

Van der Horst, Pieter W. "Did the Gentiles Know Who Abraham Was?" Pages 61-74 in Abraham, the Nations, and the Hagarites: Jewish, Christian, and Islamic Perspectives on Kinship with Abraham. Edited by Martin Goodman, George H. van Kooten and Jacques T.A.G.M. van Ruiten. Themes in Biblical Narrative. Leiden: Brill, 2010.

Vayntrub, Jacqueline. "Transmission and Mortal Anxiety in the Tale of Aqhat." Forthcoming in Like 'Ilu Are You Wise: Studies in Northwest Semitic Languages and Literature in Honor of Dennis G. Pardee. Edited by H.H. Hardy, Joseph Lam and Eric D. Raymonds. Oriental Institute Publication. Cited 8 November 2020. Online: https://core.ac.uk/reader/147828343.

Von Rad, Gerhard. Genesis: A Commentary. Revised edition. Translated by John H. Marks. OTL. London: SCM Press, 1978. 
Wikander, "Go out from Your Sign,” OTE 33/3 (2020): 556-581 581

Dr. Ola Wikander, Reader and Senior Lecturer, Centre for Theology and Religious Studies, Lund University and Pro Futura Scientia Fellow, Swedish Collegium for Advanced Study, Uppsala. Email: ola.wikander@ctr.lu.se /ola.wikander@swedishcollegium.se. ORCID: https://orcid.org/0000-0001-69061926. 